\title{
The Road Between: An Interim First Nations Accountability Regime
}

\begin{abstract}
The Government of Canada's current First Nations accountability regime is an extension of a longstanding paternalistic relationship with First Nations governments, and the struggle to build final agreements is indicative of Canada's resistance to First Nations sovereignty. This paper explores an interim accountability regime during the negotiations of these final agreements. The accountability regime will need to reconcile notions of First Nations selfgovernance to indigenize accountability both within and across First Nations. The Government of Canada can foster First Nations governance with the implementation of the Kelowna Accord and by working collaboratively with First Nations governments to identify an appropriate interim accountability regime through Outcome Management.
\end{abstract}

About the Author: Steven Cvitko is a student of the Master of Public Administration program at Dalhousie University. He obtained his Bachelor of Science in Human Ecology at the University of Alberta in 2011. He submitted this paper for a course on Organizational Design for Governance and Public Management, where he researched government accountability regimes. 


\section{Introduction}

Canada enjoys a reputation as a nation where human rights and dignity are guaranteed, democracy is respected, and diversity among peoples is celebrated. However, this reputation is undermined by a history of paternalistic, uncooperative, and wilfully destructive dominance over First Nations peoples and governments. Penetrating federal control informed the Indian Act and its continued regulation of the identities and cultures of Aboriginal peoples ${ }^{1}$, and their governments. The struggle to build final agreements is also indicative of Canada's resistance to First Nations sovereignty. Final agreements establish a framework for intergovernmental relationships between the Aboriginal, federal and, where applicable, provincial governments, and outline how First Nations governments will uphold self-governance and accountability to their peoples. As of March 2014, there were approximately 100 comprehensive land claim negotiation tables across the country, but, since 1973, only three self-government final agreements have been signed (Aboriginal Affairs and Northern Development Canada, 2014).

The Federal Accountability Act and the First Nations Financial Transparency Act dictate the Government of Canada's current accountability regime. Unsurprisingly, this accountability regime is an extension of Canada's longstanding paternalistic relationship with First Nations governments. As of November 2014, 55 First Nations were not in compliance with these acts, and "[criticized] the government for imposing the [financial transparency regulations] without consultation and argue the level of disclosure goes too far" (Curry, 2014). In response, the Government of Canada threatened to "take several actions regarding non-compliant First Nations, including withholding funding" (Curry, 2014). Halting funding to First Nations would put the quality of life of First Nations peoples at risk, thereby undermining the spirit of accountability. By promoting First Nations sovereignty alongside institutional frameworks supported by the Government of Canada, this paper aims to explore an accountability regime that will improve outcomes for First Nations peoples during the ongoing negotiations of final agreements. The accountability regime will need to reconcile notions of First Nations selfgovernance with accountability measures to ensure that the needs of First Nations citizens are met. It is argued here that the Government of Canada can foster First Nations governance by

\footnotetext{
${ }^{1}$ Aboriginal peoples in Canada comprise the Métis, Inuit, and First Nations. The term "Indian" is considered by some to be outdated. "Indian" is recognized in the Indian Act and used by the Government of Canada in place of "First Nation."
} 
working collaboratively with First Nations governments to identify an appropriate accountability regime. Self-governance and improved outcomes for Aboriginal peoples would be achieved through the implementation of the Kelowna Accord and the development of an Aboriginal funding structure that more closely resembles the structure utilized by the Australian government. Furthermore, using Outcome Management adapted to First Nations governance will indigenize accountability both within and across First Nations.

\section{Background and Context}

Starting in the early 1700s, Canada supported mutual respect and collaboration with First Nations governments, signing treaties that affirmed notions of sovereignty between two cohabitating, independent nations. The Royal Commission on Aboriginal People states that "treaties were statements of peace, friendship, sharing or alliance, not submission or surrender" (Aboriginal Affairs and Northern Development Canada, 2014). These founding principles and treaties were later subverted by a series of policies and legal documents that actively sought to destroy the sovereignty of First Nations, and the identity and culture of their peoples. In 1857, the Province of Canada passed an act, commonly known as the Gradual Civilization Act, which invited First Nations peoples and their tribal land to join Canadian society. Lawrence (2003) observes that "the nation-to-nation relationship was to all intents and purposes abandoned by Canada at that point" (p. 7). After confederation, Prime Minister John A. Macdonald announced that it would be his government's goal to "do away with the tribal system, and assimilate the Indian people in all respects with the inhabitants of the Dominion" (Aboriginal Affairs and Northern Development Canada, 2014) and Canada legally codified this goal in 1876 with the Indian Act. Milloy (2008) describes how "fundamental dualism was planted at the core of Canadian federalism" (p. 8), and two paths were forged: one for full participation of non-Aboriginal Canadians in their communities, and the other for First Nations peoples "stripped of the power of self-determination" (p. 9).

The Indian Act and Section 35 of the Constitution Act defines, clarifies, and affirms legal and governance matters pertaining to Indian status, bands, and Indian reserves. The Indian Act authorizes the Canadian government to regulate and administer governance measures regarding registered Indians and the reserve communities. The Indian Act affects all Aboriginal peoples as it defines who is and who is not an Indian, provides guidelines regarding the rights 
of Indians to practice their culture and traditions, and outlines governance structures on Aboriginal communities, such as the form of band ${ }^{2}$ councils (Justice Laws, 2014). The Indian Act is unilateral in nature and is imposed on Indigenous peoples by the Canadian government, which is in contrast to the founding principles of the treaties, as mentioned above. This contrast is a source of discontent among Aboriginals in Canada, and the Indian Act has been described as a "genocidal" regime (Lawrence, 2003, p. 4). The Indian Act's governance and status guidelines speak to the problematic relationship between Canada and Aboriginal peoples.

Yet, despite this controversy, the Indian Act is historically and legally significant for Aboriginal peoples. It acknowledges and affirms the unique historical and constitutional relationship Aboriginal peoples have with Canada. Section 35 of the Constitution Act similarly perpetuates notions of Canadian paternalism over First Nations governments but provides Aboriginal peoples and governments an institutional means to resist the violation of their rights. The Constitution relies on the Indian Act to define the existing rights of Aboriginals, and furthermore acknowledges and protects, "[A]boriginal peoples' right of self-government" (Aboriginal Affairs and Northern Development Canada, 2014).

Final agreements have been established to keep Aboriginal governments responsible to their citizens, but in instances when agreements have not been established, the Government of Canada holds First Nations governments accountable. Final agreements are being negotiated across Canada, between the federal, provincial, and First Nations governments, but in the interim, few First Nations governments control the means to their own accountability. Without an accountability framework in place, First Nations governments risk poor governance, and in some instances, corruption. In 2013, Chief Ron Giesbrecht of the Kwikwetlem First Nation in Coquitlam, British Columbia, received a startlingly disproportionate annual compensation (Walker, 2014). Due to a contractual clause that outlines a bonus structure of $10 \%$ on certain transactions, Chief Ron Giesbrecht received $\$ 800,000$ as his bonus (Walker, 2014). The bonus was for his role as economic development officer for the nation, which has not reached a final agreement, and the financial documents were released in accordance with the First Nations Financial Transparency Act (Walker, 2014). Without the disclosure, "the facts, and the

\footnotetext{
${ }^{2}$ Some "Indian" peoples have adopted the term "First Nation" to replace "Band."
} 
contrast between the nation's members' payout and the chief's windfall, would likely never have come to light" (Globe Editorial, 2014).

Over the past few decades, expectations of all levels of government, including First Nations governments, to account for improved performance and outcomes have changed. The emergence of new public management (NPM) has also reinforced the shift from the "old, ideal type of the traditional Weberian bureaucracy toward new public management approaches" (Blum and Manning, 2009, p. 42). NPM advanced the move toward reforms where "measurement [and] outcomes have been emphasized" (Ehsan, 2011, p. 137). One of the central features of NPM is an increased focus on public sector performance, promoting "a new public service culture where measured performance with the focus on results and outcomes will remain as the hallmarks of the system" (Ehsan, 2011, p. 137). Since the 1980s, the Government of Canada has adopted NPM in light of economic realities that required reduced public spending, a loss of citizen confidence in public services, and a push for global competiveness (Aucoin, 2005). This current NPM governance structure is therefore the framework in which an interim accountability regime between the Government of Canada and First Nations governments will be negotiated.

\section{Accountability in Australia}

Unlike Canada, the Australian government does not need to redefine the special legal and constitutional relationship between Aboriginals and the Australian government. During the colonization process of Australia, the colonial government's principles and actions differed from those in Canada. Morse (1984) notes, "there was no willingness whatsoever to negotiate treaties, to develop friendship, or to engage in government-to-government relations" (p. 7). As treaties were never negotiated, the legal relationship is not regulated in Australia in the same way as it is in Canada with the Indian Act. Despite the Indian Act's problematic nature, some efforts to redefine the legal relationship and outright abolish the Act have been met with widespread resistance by First Nations peoples: they were "nearly unanimous in their rejection" (Aboriginal Affairs and Northern Development Canada, 2014) of abolishing the Act. In 1969, Prime Minister Pierre Trudeau and his Minister of Indian Affairs, Jean Chrétien, unveiled a policy paper referred to as the White Paper, which proposed ending the special legal relationship between Aboriginal peoples and the Canadian government, adopting a legal 
framework more similar to the one in place in Australia. The federal government's intention was to achieve equality among all Canadians by eliminating Indian as a distinct legal status and by regarding Aboriginal peoples simply as citizens with the same rights, opportunities, and responsibilities as other Canadians. The fault of the White Paper is found in its inability to recognize the unique needs of First Nations governments. It was regarded as proposing "the end of their existence as distinct peoples" (Aboriginal Affairs and Northern Development Canada, 2014), thus actualizing Canada's longstanding attempt to assimilate First Nations peoples. The Indian Act is important to First Nations peoples in Canada. Therefore, redefining the legal framework between the government and First Nations communities will be different in Canada than in Australia, where such an act is non-existent.

Though the contextual relationship between Aboriginals and the Australian government differs from that of Canada, there is an opportunity for the Canadian government to foster Aboriginal development in similar ways to the Australian government. In 2007, the United Nations unveiled the United Nations Declaration on the Rights of Indigenous Peoples (UNDRIP), which intends to affirm the rights of all Indigenous peoples. Initially, Australia and Canada voted against UNDRIP, arguing that the level of autonomy for Aboriginals would undermine the sovereignty of their own states (Aboriginal Affairs and Northern Development, 2014; United Nations, 2007). Since 2009 and 2010, both Australia and Canada, have reversed their positions and now support the UNDRIP. Despite this support, within Australia's national boundaries the government has yet to recognize and protect Aboriginal rights constitutionally, and Pratt (2004) observes that at "first glance, Canada appears to be well ahead of Australia in its approach to recognizing Indigenous peoples' rights" (p. 44). However, Australia excels in certain areas where Canada does not. For example, since its decision to support the UNDRIP, the Australian government has implemented new policies to mitigate poor policy decisions in the past and to provide more funding to Aboriginal programming. The amount of funding, amongst other factors, affects outcomes. The Australian government has committed $\$ 19,305$ per capita ${ }^{3}$ to the Indigenous Advancement Strategy (Department of the Prime Minister and

\footnotetext{
${ }^{3}$ Adjusted to Canadian dollars and per Capita rating as per the Australian government's Department of the Prime Minister and Cabinet funding arrangement and Australian Bureau of Statistics Indigenous population estimates
} 
Cabinet, 2014; Australian Bureau of Statistics, 2014) compared to Canada's financial commitment of $\$ 9,056$ per capita (Gerson, 2013). The funding for aboriginal programming in Australia leads to better outcomes for Aboriginals, such as lower suicide rates. In Australia, the suicide rate for Aboriginal males is 90.8 per 100,000 deaths and for females is 21.8 per 100,000 (Australian Bureau of Statistics, 2014), compared to 126 per 100,000 and 35 per 100,000 for male and female Aboriginals in Canada, respectively (Health Canada, 2014). The Australian government provides funding to Aboriginal groups, and is ultimately held accountable for the wellbeing of this demographic.

\section{Accountability in Canada}

The Canadian federal government has two acts used to control accountability measures for First Nations governments, both of which undermine the potential for First Nations to selfgovern. The Federal Accountability Act of 2006 places an onus on public institutions, including First Nations governments, "to account for public spending in an open and transparent manner" (Prince, 2011, p. 325). The First Nations Financial Transparency Act of 2013 requires that First Nations make their audited consolidated financial statements and a schedule of remuneration and expenses available to their members, as well as publish it. These acts strengthen administrative control, and audit and oversight functions of government and parliament, thus "depoliticizing Canada-Aboriginal relations and disempowering First Nations" (Prince, 2011, p. 327). Though they emphasize interdependence between First Nations and the federal government, the logic of the model suggests that most First Nations governments cannot control the administrative apparatus that shapes Aboriginal lives. First Nations governments must continue to be "municipal-like governments, junior partners to Ottawa, under close supervision by the Department of Indian Affairs and other federal agencies" (Prince, 2011, p. 327), further perpetuating Canada's paternalistic relationship with First Nations governments and inhibiting efforts for self-governance.

The Accountability and the First Nations Financial Transparency Acts hold chiefs to account, but implementation of the Kelowna Accord would foster self-governance and meet the needs of First Nations citizens. In 2005, the Canadian government under the leadership of Paul Martin's Liberals worked collaboratively alongside First Nations governments to find solutions to the ongoing struggles of First Nations peoples and developed the Kelowna Accord. The 
Kelowna Accord sought to improve the education, employment, and living conditions for Aboriginal peoples through approximately 600 million Canadian dollars of governmental funding for First Nations development programming. Under the Accord, the Government of Canada and First Nations governments developed an appropriate accountability regime that entailed First Nations governments to "being accountable and reporting regularly to their respective constituencies on achieving progress" (Justice Laws, 2014). Ultimately, the Accord left room for First Nations governments to control their processes to achieve "agreed-upon culturally relevant indicators" (Justice Laws, 2014) or outcomes. In 2006, the Liberal government fell, triggering an election won by Stephen Harper's Conservatives. When the Conservative government tabled their first budget, they said they were "committed to meeting the targets of the Kelowna deal" but "[the Kelowna Accord] was not a priority in [Harper's] budget as first Prime Minister" (CBC News Online, 2006). Though the Conservative government expressed concern over the funding, data, and fiduciary relationship, with "sufficient resources and perseverance" (Patterson, 2006) the Kelowna Accord would foster self-governance and improve the lives of First Nations, Métis, and Inuit peoples.

\section{Outcome Management}

Outcome Management ensures that First Nations governments have self-determination and control over the processes and outcomes for their peoples. Outcome Management is a strategic approach to ensure that "initiatives are designed around [intended] outcomes" (Treasury Board of Canada Secretariat, 2014). Using Outcome Management, First Nations governments can actualize their own accountability management, similar to a project manager's control of their own process within a wider framework. In collaboration with the Government of Canada, First Nations governments can identify "milestones" (Treasury Board of Canada Secretariat, 2014) or leading indicators towards attaining the desired outcomes for First Nations peoples. These milestones can exist throughout a variety of social, cultural, and economic fields, like employment, health, economic development, education, and other pillars of wellbeing. The Outcome Management model is an appropriate, institutionalized framework for the Government of Canada to reconcile the need for First Nations accountability measures and self-governance. 
Outcome Management would encourage a "whole of government solution approach" (Treasury Board of Canada Secretariat, 2014) to establishing and obtaining outcomes for First Nations peoples. Outcome Management guides all governments to group information and services around the needs and priorities of clients, not around organization and delegation of governments. Furthermore, this framework builds partnerships among governments to cluster services, rather than according to jurisdictions. In 2006, the Outcome Management framework fostered the collaboration of 34 departments and agencies for the Government On-Line initiative to make government more responsive, innovative, and accountable. As Canadian and First Nations governments are accountable for the needs of First Nations before final agreements are negotiated, Outcome Management supports a nation-to-nation collaborative arrangement to improve outcomes for clients, where all governments are ultimately accountable. Outcome Management is well suited for building self-governance between and within First Nations governments and the federal government, to ensure that improved outcomes are met.

\section{Final Agreement}

Though complex and time-consuming, the Government of Canada and First Nations governments have successfully developed self-governance agreements that ensure accountability standards are met for First Nations peoples. For example, the Tsawwassen First Nation reached a final agreement with the Governments of Canada and British Columbia and established an accountability regime that provides "for a system of financial administration with standards comparable to those generally accepted for governments in Canada" (Aboriginal Affairs and Northern Development Canada, 2014). This agreement highlights a breakthrough for First Nations self-governance in Canada, but involved a long and time-consuming process that lasted nearly 14 years. Similarly, the negotiation of the Nunavut Act and the Nunavut Land Claims Agreement Act in 1999, that established Nunavut as an Inuit self-government territory, dated back to the formation of the Inuit Tapirisat of Canada in the early 1970s. Though the long negotiation process hinders First Nations independence, the Tsawwassen First Nation and Nunavut final agreements are ground-breaking examples of where modern-day treaty and agreement-making process can develop accountability regimes within self-governance for First 
Nations governments. Achieving more final agreements remains a critical piece in attaining lasting certainty, true reconciliation, and better outcomes for First Nations peoples.

Ultimately, to ensure the long-term protection of First Nations sovereignty rights, the paternalistic Indian Act would need to be entirely reworked from its current form: the Constitution would need to be reopened, and section 35 would need to be revised. Historically, changes to the Indian Act have been imposed unilaterally by Canada, but if self-governance and self-determination is to be achieved, then First Nations governments must have a hand in future Indian Act revisions. Furthermore, the "non-specific nature" of the constitutional text means that Canadian Aboriginal resources, such as funding and programming, and willingness to work collaboratively with First Nations governments will always "depend on the government of the day" (Brunet-Jailly, 2008, p. 8) and so First Nations' autonomy and potential are not guaranteed. If the Constitution Act is reopened, then the pressure to deal with other provincial affairs and governance issues will distract the conversation, and undermine the voices of First Nations governments. As Bryden (2011) observes about the Meech and Charlottetown constitutional revisions, negotiations quickly became a "swamp of conflicting demands from provinces and various interest groups." To mitigate these distractions, the intents and purpose of constitutional revisions regarding First Nations governance will need to be supported and affirmed by Canada.

While final agreements are being negotiated, the Government of Canada has a responsibility to uphold the collaborative spirit of the treaties and to improve outcomes for First Nations peoples. The current accountability regime, dictated by the Accountability Act and the First Nations Financial Transparency Act, cannot accommodate any notion of self-governance for First Nations governments, and current funding arrangements are not adequately improving First Nations peoples' quality of life. This accountability regime must be replaced with a framework such as Outcome Management to foster an environment conducive to selfgovernance. Furthermore, implementation of the Kelowna Accord will ensure that the needs of First Nations citizens are met. The accountability system for a First Nation will be a "negotiated order; the result of bargaining compromising by all sides, learning and adapting practices over time" (Prince, 2011, p. 327). The federal government must take the opportunity to empower 
First Nations governments and promote governance systems with the capacity, size, resources and legitimacy to provide effective governance for and by Aboriginal peoples. 


\section{References}

Aboriginal Affairs and Northern Development Canada. (2014). Acts, agreements, treaties, and land claims. Government of Canada. Retrieved from https://www.aadncaandc.gc.ca/eng/1100100028568/1100100028572

Aboriginal Affairs and Northern Development Canada. (2014). Canada's endorsement of the United Nations Declaration on the Rights of Indigenous Peoples. Government of Canada. Retrieved from http://www.aadncaandc.gc.ca/eng/1309374807748/1309374897928

Aboriginal Affairs and Northern Development Canada. (2014). Highlights from the report of the Royal Commission on Aboriginal peoples. Government of Canada. Canadian Catalogue no. Z1-1991/1-6E. Retrieved from http://www.aadncaandc.gc.ca/eng/1100100014597/1100100014637\#chp3

Aboriginal Affairs and Northern Development Canada (2014). Tsawwassen First Nation Final Agreement, 2006, Chapter 16 8(g). Government of Canada. Retrieved from https://www.aadnc-aandc.gc.ca/eng/1100100022706/1100100022717

Aucoin, P. (1995). The new public management: Canada in comparative perspective. Montreal: Institute for Research on Public Policy.

Australian Bureau of Statistics. (2014). Aboriginal and Torres Strait Islander suicide deaths. Catalogue number 3309.0 - Suicides, Australia, 2010. Retrieved from http://www.abs.gov.au/ausstats/abs@.nsf/Products/3309.0 2010 Chapter Aborigin al+and+Torres+Strait+Islander+suicide+deaths?OpenDocument

Australian Bureau of Statistics. (2014). Estimates of Aboriginal and Torres Strait Islander Australians, June 2011. Australian Government. Australian Government Catalogue number 3238.0.55.001. Retrieved from http://www.abs.gov.au/ausstats/abs@.nsf/mf/3238.0.55.001

Blum, J \& Manning, N. (2009). Public management reforms across OECD countries. Public Management and Governance ( $2^{\text {nd }}$ ed.). Tony Bovaird and Elke Loffler (Eds.). New York: Routledge.

Brunet-Jailly, E. (2008). The governance and fiscal environment of First Nations' fiscal intergovernmental relations in comparative perspectives. National Centre for First Nations Governance. Retrieved from http://fngovernance.org/ncfng_research/emmanual_brunet-jailley.pdf

Bryden, J. (2011). Most Canadians now willing to reopen Constitution, poll finds. The Globe and Mail. The Canadian Press: Ottawa. Retrieved from 
http://www.theglobeandmail.com/news/politics/most-canadians-now-willing-toreopen-constitution-poll-finds/article581354/

CBC News Online. Undoing the Kelowna Accord. In Depth: Aboriginal Canadians. CBC News. Retrieved from http://www.cbc.ca/news2/background/aboriginals/undoingkelowna.html

Curry, B. (2014). More than 90 per cent of First Nations comply with transparency law. Globe and Mail: Ottawa. Retrieved from http://www.theglobeandmail.com/news/politics/more-than-90-per-cent-of-firstnations-comply-with-transparency-law/article21816978/

Department of the Prime Minister and Cabinet. (2014). Indigenous Affairs Advancement Strategy. Australian Government. Retrieved from http://www.dpmc.gov.au/indigenous_affairs/ias/index.cfm

Ehsan, M. (2011). The evolution of performance management systems. Approaching Public Administration: Core Debates and Emerging Issues (pp. 137-151). Toronto: Emond Montgomery Publications Ltd.

Gerson, J. (2013). Federal funding not a problem for First Nations as yearly spending has risen to $\$ 9,056$ per capita, study finds. National Post. Retrieved from http://news.nationalpost.com/2013/12/10/federal-funding-not-a-problem-for-firstnations-as-yearly-spending-has-risen-to-9056-per-capita-study-finds/

Globe Editorial. (2014). With the First Nations Financial Transparency Act, seeing is believing. The Globe and Mail. Retrieved from http://www.theglobeandmail.com/globedebate/editorials/with-the-first-nations-financial-transparency-act-seeing-isbelieving/article20082359/

Health Canada (2014). Mental health and wellness. First Nations and Inuit Health. Retrieved from http://www.hc-sc.gc.ca/fniah-spnia/promotion/mental/index-eng.php

Justice Laws. (2014). The Indian Act, 1985, I-5. Government of Canada: Ottawa ON. Retrieved from http://laws-lois.justice.gc.ca/eng/acts/i-5/page-1.html

Justice Laws (2014). The Kelowna Accord Implementation Act. Government of Canada: Ottawa ON. Retrieved from http://laws-lois.justice.gc.ca/eng/acts/K-0.65/page-1.html

Lawrence, B. (2003). Gender, race, and the regulation of Native identity in Canada and the United States: An overview. Hypatia, 18(2), 3-31.

Milloy, J. (2008). Indian Act colonialism: A century of dishonour, 1869-1969. National Centre for First Nations Governance. Retrieved from http://fngovernance.org/ncfng_research/milloy.pdf 
Morse, B. (1984). Aboriginal self-government in Canada and Australia. Institute of Intergovernmental Relations: Kingston, ON. Retrieved from http://www.queensu.ca/iigr/pub/archive/aboriginalpapers/background/BG4Aboriginal Self-GovernmentInAustraliaandCanada.pdf

Patterson, L (2006). Aboriginal roundtable to Kelowna Accord: Aboriginal policy negotiations, 2004-2005. Parliament of Canada: Ottawa, ON. Catalogue number PRB 06-04E. Retrieved from http://www.parl.gc.ca/Content/LOP/researchpublications/prb0604e.htm

Pratt, A. (2004). Treaties vs. Terra Nullius: "Reconciliation," treaty-making and Indigenous sovereignty in Australia and Canada. Indigenous Law Journal, 3, Fall 2014: 43-60.

Prince, M. (2011). Federal accountability regimes and First Nations governance. Approaching Public Administration: Core Debates and Emerging Issues (pp. 325-331). Toronto: Emond Montgomery Publications.

Treasury Board of Canada Secretariat. (2014). Outcome Management. Government of Canada. Retrieved from http://www.tbs-sct.gc.ca/emf-cag/outcome-resultat/lessonslecons/lessons-lecons02-eng.asp

United Nations. (2007). General Assembly adopts Declaration on Rights of Indigenous Peoples; "Major step forward" towards human rights for all, says president. Meetings Coverage and Press Releases. General Assembly. Retrieved from http://www.un.org/press/en/2007/ga10612.doc.htm

Walker, C. (2014). Chief Ron Giesbrecht won't resign after $\$ 1 \mathrm{M}$ payday controversy. CBC News. Retrieved from http://www.cbc.ca/news/aboriginal/chief-ron-giesbrecht-won-tresign-after-1m-payday-controversy-1.2730320 